\title{
Effects of some processing factors on the characteristics of stored groundnut milk extract
}

\author{
ADEIYE Oluwasijibomi Adesola, GBADAMOSI Saka Olasunkanmi* and TAIWO Adekunbi \\ Kehinde
}

Department of Food Science and Technology, Obafemi Awolowo University, Ile-Ife, Nigeria.

Accepted 19, April 2013

\begin{abstract}
The purpose of this work was to investigate the influence of processing variables on some properties of stored groundnut milk extracts (GME). GMEs were prepared from fresh, roasted $\left(170{ }^{\circ} \mathrm{C}, 25 \mathrm{~min}\right)$ and steeped (water, $20 \mathrm{~min}$ ) groundnuts. The groundnuts were milled, sieved, the slurry boiled, homogenized, pasteurized and stored. The GMEs packaged in glass bottles, plastic bottles and low density polyethylene sachets, were stored in the refrigerator for 28 days and at room temperature for three days and tested for proximate composition, physico-chemical and sensory properties. The protein contents of the GME varied between 2.05 to 2.33\%; fat, 2.40 to $3.48 \%$; carbohydrate, 5.50 to $5.60 \%$; viscosity, 7.33 and $7.56 \mathrm{cP}$; titratable acidity, 0.10 to $0.14 \%$ and $\mathrm{pH}, 6.82$ to 6.85 . The protein and fat contents of GMEs decreased with storage time regardless of the packaging materials and processing pretreatment. The GMEs were not different in terms of taste and mouth feel but recorded significant differences in colour, appearance and flavour.
\end{abstract}

Key words: Dehulling, roasting, homogenization, groundnut milk, physico-chemical, proximate composition, viscosity, titratable acidity, specific gravity, packaging.

\section{INTRODUCTION}

Milk is a highly nutritious and versatile food consumed by virtually everyone in various forms but mainly by children and provides the primary source of nutrition for newborns. Milk may be consumed in its natural form or used to make a wide range of food products, including cream, butter, yoghurt, cheese and ice-cream (Potter and Hotchkiss, 1996). Prior to the development of vegetable milk and vegetable milk products, direct consumption of milk and milk products was not common in Nigeria (Onweluzo and Owo, 2005). The scarcity of fresh milk supply in developing countries perhaps led to the development of alternative milk from vegetable sources. A wide variety of milk-like products can be obtained from oilseeds including groundnut, coconut, soybean and chestnuts. The growing awareness of the nutrition benefits of plant based foods by health conscious consumers has renewed interest in the development of vegetable milk and vegetable milk products (Diarra et al., 2005). Milk extracts from these products can be used as supplements in the diets of pre-school and school children or it can be used as substitute for ordinary milk, if allergic condition develops. Several researchers have worked on the development of vegetable milk from legumes and oilseeds (Onweluzo and Nwakalor, 2009; Asiamah, 2005).

Among the sources of vegetable milk, soybean has received considerable attention (Sunny-Roberts et al., 2004; Wang et al., 2002; Wang et al., 2003). Compared to soybean relatively little research attention has been given to peanut as a source of vegetable milk in spite of its high level of protein content. There is global shortage of proteins and groundnut can play a useful role in 
alleviating these deficiencies because of its rich content of protein. Groundnut contains more protein than meat, about two and half times more than eggs and far more than any other vegetable food except soybean and yeast (Sanni et al., 1999). This work therefore was aimed at optimizing processing conditions and evaluating the packaging materials with a view to producing good quality groundnut milk extract of acceptable keeping quality.

\section{MATERIALS AND METHODS}

\section{Sample preparation}

Dried shelled groundnuts (Arachis hypogaea) were purchased from a local market in Ile - Ife, Osun State, Nigeria. The seeds were cleaned manually to remove impurities and were then divided into three portions. The first portion of groundnuts was roasted at $170^{\circ} \mathrm{C}$ for $25 \mathrm{~min}$ in a hot air oven (Nulec, FSC 2003, Japan) with intermittent stirring. The nuts were allowed to cool in the open and then manually dehulled to obtain roasted groundnuts. The second portions of the nuts were prepared by soaking the nuts in tap water for $20 \mathrm{~min}$ at room temperature $\left(28 \pm 2^{\circ} \mathrm{C}\right)$ to facilitate dehulling. The water was decanted and the nuts manually washed to remove the skin as described by Onweluzo and Nwakalor (2009) and Ojofeitimi et al. (2001) to obtain steeped groundnut. The last portions of groundnut samples were untreated nuts and referred to as fresh groundnuts.

\section{Preparation of groundnut milk samples}

Three hundred grams of the groundnut samples were milled with $500 \mathrm{ml}$ of distilled water to obtain a fine paste using an electric blender (Philips, HR2815, and Holland) set at $2000 \mathrm{rpm}$ for $10 \mathrm{~min}$. The volume was made up to $750 \mathrm{ml}$ with water and the slurry sieved to remove the chaff using a double layered cheese cloth. Approximately $250 \mathrm{ml}$ of sucrose solution containing $125 \mathrm{~g}$ of sucrose was added to the milk slurry to obtain $1 \mathrm{~L}$ of milk (SunnyRoberts et al., 2004; Ojofeitimi et al., 2001). The creamy milk obtained was boiled in a covered stainless steel pot at $100{ }^{\circ} \mathrm{C}$ for 10 min, homogenized at 15 psi for 15 min (Stansted Homogenizer Systems, England) and packaged $(150 \mathrm{ml})$ in clean dried glass bottles, plastic bottles and low density polyethylene (LDPE) sachets. The sachet was heat sealed using an impulse sealer (MEC, China). Samples were pasteurized (in a covered water bath) at $65^{\circ} \mathrm{C}$ for $30 \mathrm{~min}$, cooled and then stored at refrigeration temperature $\left(3\right.$ to $\left.5^{\circ} \mathrm{C}\right)$ for a period of 28 days and at room temperature for three days (Sunny-Roberts et al., 2004, Ojofeitimi et al., 2001).

\section{Physicochemical analysis}

\section{Proximate analysis}

The proximate composition (moisture, lipid, ash, crude fibre, crude protein (nitrogen content was multiplied by 6.25) and carbohydrate obtained by difference) was carried out on the fresh and processed groundnut samples as well as samples of groundnut cake and GMEs using standard methods of analysis (AOAC, 1990).

\section{Titratable acidity}

Twenty grams of the GME was weighed into a $250 \mathrm{ml}$ conical flask and diluted with twice its volume of distilled water. $2 \mathrm{ml}$ of phenolphthalein indicator was added to the mixture and this was titrated with $0.1 \mathrm{~N}$ sodium hydroxide $(\mathrm{NaOH})$ to persistent pink colour. The titratable acidity was reported as \% lactic acid by weight using $1 \mathrm{ml} 0.1 \mathrm{~N} \mathrm{NaOH}=0.0090 \mathrm{~g}$ lactic acid (AOAC, 1990).

\section{Specific gravity and viscosity}

Specific gravity was determined at room temperature by the use of a standardized hydrometer (Hydrometer, Ansbach, Germany) immersed in the milk. The viscosity was determined using a digital viscometer NDJ-85 (Shanghai Niun Intelligent Technology Co. Ltd, China).

\section{Visual observation (stability test)}

This was carried out to determine the rate at which the milk emulsion separated during storage using the method of Priepke et al. (1980). Freshly prepared GME was filled into graduated transparent universal bottles to a reference level. The bottles were observed every day for separation, formations of curdles and changes in colour.

Sensory evaluation was conducted using 10 panelists supplied with coded samples of the three types of freshly-prepared GME. They were also supplied with coded commercial soya milk and commercial cow milk. Panelists tested for appearance, flavour, taste, mouth feel, colour and overall acceptability of the samples using a 9 point hedonic scale with 9 as "like extremely" and 1 as "dislike extremely". The result was subjected to analysis of variance (ANOVA).

\section{Statistical analysis}

All experiments were conducted in triplicate. Data reported are averages of three determinations. Analysis of variance (ANOVA) was performed and differences in mean values were evaluated using Tukey`s test at $p<0.05$.

\section{RESULTS AND DISCUSSION}

\section{Proximate composition of pre-treated groundnut and groundnut cake samples}

The results of the proximate composition of groundnut samples before and after milk extraction are shown in Table 1. The protein content of pretreated samples ranged between 13.05 and $20.92 \%$, with the roasted sample having the highest value of $20.92 \%$. This was not unexpected since groundnut proteins undergo changes during roasting (Weiss, 1983). The protein contents of the groundnut cake (3.67 to $5.71 \%$ ) samples were lower than the protein contents of groundnut samples before milk extraction. The difference (depending on the pretreatment) could have been extracted into the milk solution. The moisture content varied between 3.79 to $33.09 \%$ with the roasted groundnut sample exhibiting the lowest value. Steeping was done in order to dehull the groundnut samples hence the high moisture value for dehulled samples. The moisture content values obtained in this study were within the range of values previously 
Table 1. Proximate composition (\%) of pre-treated groundnut samples and groundnut cakes

\begin{tabular}{lcccccc}
\hline Sample & Moisture & Ash & Protein & Crude fat & Crude fibre & Carbohydrate \\
\hline Raw & $8.40^{\mathrm{b}}$ & $3.98^{\mathrm{d}}$ & $19.46^{\mathrm{d}}$ & $46.87^{\mathrm{e}}$ & $2.32^{\mathrm{d}}$ & $18.97^{\mathrm{c}}$ \\
Roasted & $3.79^{\mathrm{a}}$ & $4.09^{\mathrm{e}}$ & $20.92^{\mathrm{d}}$ & $52.38^{\mathrm{f}}$ & $2.47^{\mathrm{d}}$ & $16.35^{\mathrm{b}}$ \\
Steeped & $33.09^{\mathrm{c}}$ & $2.60^{\mathrm{c}}$ & $13.05^{\mathrm{c}}$ & $27.43^{\mathrm{d}}$ & $1.68^{\mathrm{c}}$ & $22.15^{\mathrm{d}}$ \\
Steeped cake & $66.95^{\mathrm{e}}$ & $0.96^{\mathrm{a}}$ & $3.67^{\mathrm{a}}$ & $10.09^{\mathrm{b}}$ & $0.23^{\mathrm{a}}$ & $18.10^{\mathrm{c}}$ \\
Raw cake & $77.67^{\mathrm{f}}$ & $1.67^{\mathrm{b}}$ & $4.51^{\mathrm{b}}$ & $8.97^{\mathrm{a}}$ & $0.51^{\mathrm{b}}$ & $6.67^{\mathrm{a}}$ \\
Roasted cake & $54.58^{\mathrm{d}}$ & $1.86^{\mathrm{b}}$ & $5.71^{\mathrm{b}}$ & $21.60^{\mathrm{c}}$ & $0.50^{\mathrm{b}}$ & $15.75^{\mathrm{b}}$ \\
\hline
\end{tabular}

Steeped groundnut, seeds soaked in water for $20 \mathrm{~min}$; roasted, seeds oven heated at $170^{\circ} \mathrm{C}$ for 25 min. *Means within a column followed by different letters are significantly different $(p<0.05)$.

Table 2. Physico-chemical properties of groundnut milk samples.

\begin{tabular}{lcccc}
\hline Quality characteristics & $\begin{array}{c}\text { Milk from roasted } \\
\text { groundnut }\end{array}$ & $\begin{array}{c}\text { Milk from whole } \\
\text { groundnut }\end{array}$ & $\begin{array}{c}\text { Milk from steeped } \\
\text { groundnut }\end{array}$ & Cow milk $^{\star}$ \\
\hline Protein (\%) & $2.33^{\mathrm{b}}$ & $2.29^{\mathrm{b}}$ & $2.05^{\mathrm{a}}$ & $3.29^{\mathrm{c}}$ \\
Fat (\%) & $3.48^{\mathrm{c}}$ & $2.40^{\mathrm{a}}$ & $2.90^{\mathrm{b}}$ & $3.34^{\mathrm{b}}$ \\
Moisture (\%) & $82.49^{\mathrm{a}}$ & $86.15^{\mathrm{b}}$ & $87.26^{\mathrm{c}}$ & $87.99^{\mathrm{c}}$ \\
Carbohydrate (\%) & $5.60^{\mathrm{b}}$ & $5.50^{\mathrm{b}}$ & $5.50^{\mathrm{b}}$ & $4.66^{\mathrm{a}}$ \\
Titratable acidity (\% lactic acid) & $0.10^{\mathrm{a}}$ & $0.14^{\mathrm{b}}$ & $0.10^{\mathrm{a}}$ & $0.10^{\mathrm{a}}$ \\
pH & $6.85^{\mathrm{c}}$ & $6.85^{\mathrm{c}}$ & $6.82^{\mathrm{a}}$ & $6.80^{\mathrm{b}}$ \\
Specific gravity at $20^{\circ} \mathrm{C}$ & $1.032^{\mathrm{a}}$ & $1.030^{\mathrm{a}}$ & $1.030^{\mathrm{a}}$ & $1.031^{\mathrm{a}}$ \\
\hline
\end{tabular}

${ }^{*}$ Akinyele (1983). *Means within a row followed by different letters are significantly different $(p<0.05)$.

reported for legumes by Olaofe and Sanni (1988) and Oyenuga (1968). Whole and roasted groundnut samples had comparable ash contents which were higher than in the steeped samples and which may be attributed to the presence of seed coats (Ihekoronye and Ngoddy, 1985). The crude fibre content (1.68 to $2.47 \%$ ) indicated that groundnut could play a role in normal peristaltic movement of the intestinal tract (Akinyele, 1983). Roasted groundnut cake had the lowest moisture content which is an advantage when shelf life is considered. The low moisture content of the cake from roasted groundnuts is not unexpected as the heat may have denatured the proteins and starch components of the carbohydrate gelatinized both of which will affect their water absorption abilities (Gbadamosi and Ogunsua, 2006). The presence of the skin may contribute to the high moisture content of cake from whole groundnut samples. Apart from leaching of compounds during extraction, the absorption of water accounts for the reduced values of other components in the cakes.

\section{Physico-chemical properties of GMEs}

The results in Table 2 show some of the chemical and physical properties of the milk extracts obtained from different pre-treated groundnut samples. The protein values (2.05 to $2.33 \%$ ) of the GMEs were significantly lower $(p<0.05)$ than that of the cow milk. It was also observed that the protein content of the GMEs was less than the difference between the protein contents of the groundnut samples before and after milk extraction (Table 1) which implied that not all the protein in the groundnut sample was extracted into the milk extract. The carbohydrate content of groundnut milk samples $(5.5$ to $5.6 \%$ ) was higher than that of cow milk (4.6\%) irrespective of the pretreatment which makes GME a veritable source of calories for feeding infants. Fat content of GME from roasted groundnut was comparable $(3.48 \%)$ to that of cow milk $(3.34 \%)$ while the fat content of milk from steeped and whole groundnut was lower (2.40 to 2.90 ). The titratable acidity of the groundnut milk samples $(0.10$ to 0.14$)$ compared favorably with that of cow milk (0.10) so also the $\mathrm{pH}(6.80$ to 6.82$)$ and specific gravity (1.030 to 1.032). These values are similar to those reported for reconstituted powered milk and soybean milk blends (Miller, 2000). The implication of this is that GME may be a good substitute for cow milk with respect to these attributes.

Table 3 shows changes in physico-chemical properties of the different GMEs preparations stored at room and at refrigerated temperatures for three days. GMEs stored at room temperature fared poorly compared to the refrigerated samples. On the $3^{\text {rd }}$ day, the protein content of 
Table 3. Physico-chemical properties of GME stored in different packaging materials at refrigerated and at room temperatures for 3 days.

\begin{tabular}{|c|c|c|c|c|c|c|c|}
\hline \multirow{2}{*}{$\begin{array}{l}\text { Quality } \\
\text { characteristic }\end{array}$} & \multirow{2}{*}{$\begin{array}{l}\text { Packaging } \\
\text { material }\end{array}$} & \multicolumn{2}{|c|}{ Roasted } & \multicolumn{2}{|c|}{ Whole } & \multicolumn{2}{|c|}{ Steeped } \\
\hline & & $\left(4^{\circ} \mathrm{C}\right)$ & $\left(28^{\circ} \mathrm{C}\right)$ & $\left(4^{\circ} \mathrm{C}\right)$ & $\left(28^{\circ} \mathrm{C}\right)$ & $\left(4^{\circ} \mathrm{C}\right)$ & $\left(28^{\circ} \mathrm{C}\right)$ \\
\hline \multirow{3}{*}{ Protein } & Plastic & $2.12^{\mathrm{c}}$ & $1.24^{\mathrm{a}}$ & $2.29^{d}$ & $1.40^{b}$ & $2.05^{c}$ & $1.22^{\mathrm{a}}$ \\
\hline & Glass & $2.11^{\mathrm{e}}$ & $1.10^{\mathrm{b}}$ & $2.18^{\mathrm{e}}$ & $1.20^{\mathrm{c}}$ & $1.91^{\mathrm{d}}$ & $0.99^{\mathrm{a}}$ \\
\hline & Sachet & $1.98^{\mathrm{C}}$ & $0.88^{\mathrm{b}}$ & $2.01^{\mathrm{C}}$ & $0.91^{\mathrm{b}}$ & $2.02^{\mathrm{C}}$ & $0.65^{a}$ \\
\hline \multirow{3}{*}{ Fat } & Plastic & $3.27^{\mathrm{e}}$ & $1.98^{\mathrm{b}}$ & $2.18^{\mathrm{b}}$ & $1.21^{\mathrm{a}}$ & $2.72^{d}$ & $1.38^{\mathrm{c}}$ \\
\hline & Glass & $3.32 f$ & $1.90^{\mathrm{C}}$ & $2.22^{d}$ & $1.55^{\mathrm{a}}$ & $2.81^{\mathrm{e}}$ & $1.72^{\mathrm{b}}$ \\
\hline & Sachet & $3.32^{\mathrm{e}}$ & $1.10^{\mathrm{a}}$ & $2.30^{\mathrm{C}}$ & $1.45^{\mathrm{b}}$ & $2.74^{d}$ & $1.45^{\mathrm{b}}$ \\
\hline \multirow{3}{*}{ Moisture } & Plastic & $82.14^{\mathrm{a}}$ & $82.00^{\mathrm{a}}$ & $84.70^{c}$ & $83.98^{b}$ & $87.16^{d}$ & $87.00^{d}$ \\
\hline & Glass & $82.02^{\mathrm{a}}$ & $82.02^{a}$ & $85.15^{b}$ & $85.15^{b}$ & $87.16^{c}$ & $87.16^{c}$ \\
\hline & Sachet & $81.61^{\mathrm{a}}$ & $81.61^{a}$ & $84.20^{C}$ & $83.20^{b}$ & $87.15^{\mathrm{e}}$ & $86.15^{d}$ \\
\hline \multirow{3}{*}{ Carbohydrate } & Plastic & $5.60^{\mathrm{e}}$ & $3.65^{\mathrm{c}}$ & $5.50^{d}$ & $3.45^{\mathrm{b}}$ & $5.50^{d}$ & $3.32^{\mathrm{a}}$ \\
\hline & Glass & $5.60 f$ & $3.98^{\mathrm{C}}$ & $5.50^{\mathrm{e}}$ & $3.52^{\mathrm{a}}$ & $5.00^{d}$ & $3.59^{b}$ \\
\hline & Sachet & $5.30^{d}$ & $3.24^{\mathrm{a}}$ & $5.39^{\mathrm{e}}$ & $3.82^{\mathrm{b}}$ & $5.33^{d}$ & $3.91^{\mathrm{c}}$ \\
\hline \multirow{3}{*}{$\begin{array}{l}\text { Titratable } \\
\text { acidity }\end{array}$} & Plastic & $0.10^{\mathrm{a}}$ & $0.29^{c}$ & $0.14^{\mathrm{b}}$ & $0.30^{c}$ & $0.10^{\mathrm{a}}$ & $0.29^{c}$ \\
\hline & Glass & $0.10^{\mathrm{a}}$ & $0.25^{\mathrm{C}}$ & $0.11^{\mathrm{a}}$ & $0.26^{c}$ & $0.10^{\mathrm{a}}$ & $0.20^{\mathrm{b}}$ \\
\hline & Sachet & $0.10^{\mathrm{a}}$ & $0.29^{c}$ & $0.12^{\mathrm{a}}$ & $0.21^{b}$ & $0.10^{\mathrm{a}}$ & $0.28^{\mathrm{c}}$ \\
\hline \multirow{3}{*}{$\mathrm{pH}$} & Plastic & $6.60^{d}$ & $5.60^{\circ}$ & $6.85^{\mathrm{e}}$ & $4.48^{\mathrm{b}}$ & $6.82^{\mathrm{e}}$ & $4.12^{\mathrm{a}}$ \\
\hline & Glass & $5.79^{c}$ & $5.00^{b}$ & $6.82^{d}$ & $4.11^{a}$ & $6.82^{d}$ & $4.09^{\mathrm{a}}$ \\
\hline & Sachet & $6.50^{c}$ & $5.40^{\mathrm{b}}$ & $6.83^{d}$ & $4.12^{\mathrm{a}}$ & $6.80^{d}$ & $4.11^{\mathrm{a}}$ \\
\hline \multirow{3}{*}{$\begin{array}{l}\text { Specific } \\
\text { gravity }\end{array}$} & Plastic & $1.032^{\mathrm{a}}$ & $1.034^{\mathrm{a}}$ & $1.030^{\mathrm{a}}$ & $1.033^{\mathrm{a}}$ & $1.030^{\mathrm{a}}$ & $1.032^{\mathrm{a}}$ \\
\hline & Glass & $1.032^{\mathrm{a}}$ & $1.034^{\mathrm{a}}$ & $1.030^{\mathrm{a}}$ & $1.033^{\mathrm{a}}$ & $1.030^{\mathrm{a}}$ & $1.033^{\mathrm{a}}$ \\
\hline & Sachet & $1.034^{\mathrm{a}}$ & $1.036^{\mathrm{a}}$ & $1.032^{\mathrm{a}}$ & $1.034^{\mathrm{aa}}$ & $1.031^{\mathrm{a}}$ & $1.035^{\mathrm{a}}$ \\
\hline
\end{tabular}

refrigerated GME from roasted groundnut stored in glass depreciated by $9 \%$ of the day 1 value, the same sample stored at room temperature had depreciated by about $52 \%$ of the day 1 value. This pattern of results is similar irrespective of the processing method or the packaging material. A similar trend was observed for fat content and carbohydrate content. An exception to this marked depreciation is the moisture content which was relatively stable. It is known that reducing the temperature of foods reduced the rate of chemical and microbial metabolism (Adoga, 2006). It was concluded that unrefrigerated milk is not suitable for consumption beyond the day of production as also reported by Ojofeitimi et al. (2001). Further analysis of unrefrigerated milk was therefore discontinued. The packaging materials did not influence the composition of the GMEs under the storage conditions used. Acidity values of GMEs stored at room temperature $(0.20$ to 0.30$)$ were higher than those refrigerated (0.10 to 0.14$)$. $\mathrm{pH}$ of GMEs stored at room temp (4.09 to 5.60) were lower than stored in the fridge (6.50 to 6.85). pH of GME from whole and steeped groundnuts were significantly lower than those from roasted groundnut. $\mathrm{pH}$ of refrigerated GMEs were not influenced by pretreatment. Specific gravity (1.030 to 1.036) of the GMEs did not change with storage (up to day 3 at the different temperatures) and was not influenced by the packaging material.

\section{Effects of processing variables and packaging materials on the protein content of GMEs}

Protein content of GME from roasted seeds (2.33\%) was higher than that of GME from the whole seeds $2.29 \%$ (Table 2). This agrees with the results of Beuchat and Nail (1978) who reported higher protein in treated peanut milk than in the untreated milk. Figure 1a shows changes in the protein content of GME obtained from pretreated 

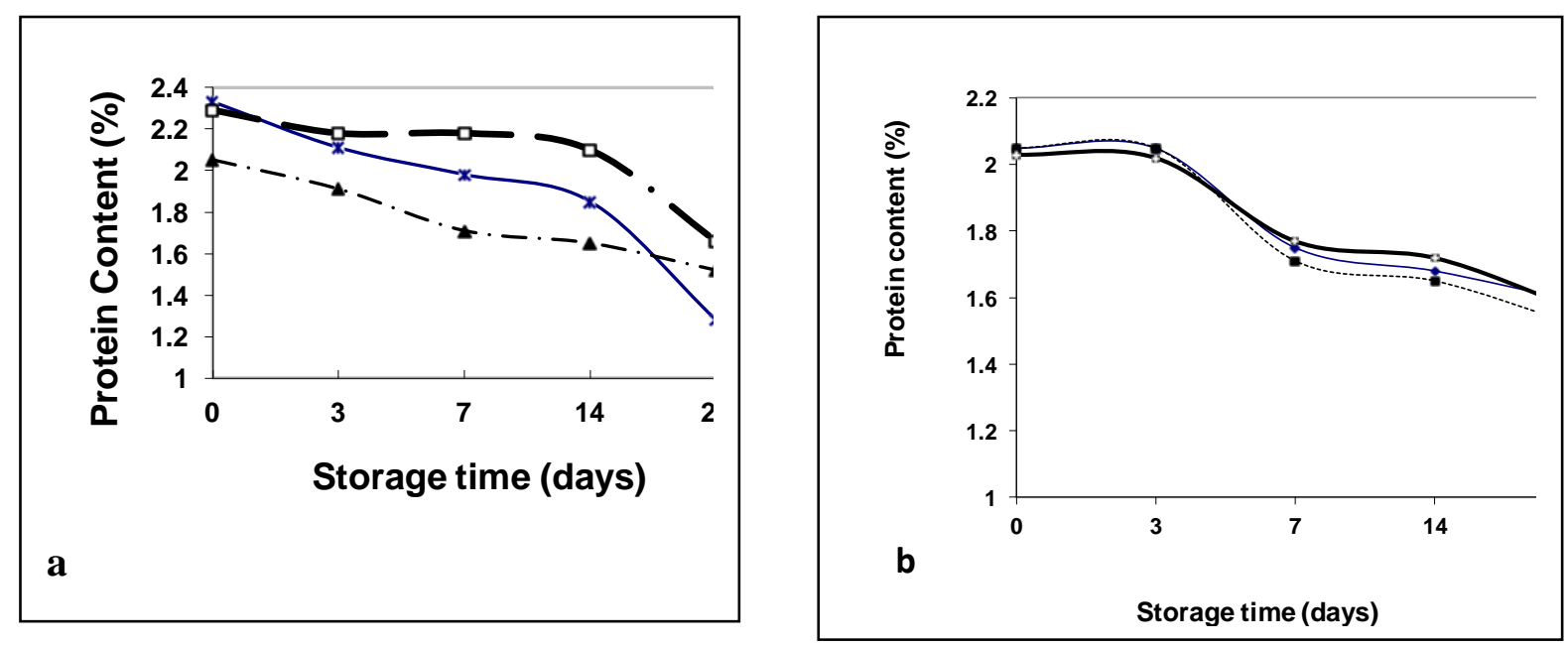

Figure 1. Effect of pretreatment and packaging materials on the protein content of stored groundnut milk: $A$ : $X$, Roasted: $\Upsilon$, whole; $\Delta$, steeped. B: $\Upsilon$, Plastic; $\Upsilon$, glass; $\Delta$, sachet.

groundnut and the GME stored in plastic. This trend is representative of results observed for samples stored in glass and sachet containers (not shown). Generally as storage time increased, there was a general decrease in the protein content of groundnut milk regardless of the packaging material. This agrees with the findings of Miller (2000) who reported a decrease in protein content of groundnut milk during storage. However milk samples from whole groundnut exhibited relatively high stability in protein content over a longer period particularly when stored in plastic and glass containers than milk from roasted or steeped groundnut samples.

The protein content in milk from roasted seeds decreased steadily from $2.12 \%$ on day 1 to $1.58 \%$ in plastic (that is, $25 \%$ reduction) and $1.22 \%$ in sachet (that is, $42 \%$ reduction) on day 14 . Thereafter, the value dropped sharply to about $1 \%$ (55\% reduction) on the $28^{\text {th }}$ day. This decrease could be due to formation of hydrofuran derivatives by amino acids and carbohydrates, a process catalyzed by the initial heat treatment. These derivatives make protein unavailable for testing as well as for intestinal absorption (Ferrer et al., 2000). It has been suggested that Maillard reaction initiated during heat treatment may be responsible for the continued degradation in protein quality during storage (Alkanhal, 2000; Evangelisti et al., 1999).

Figure $1 \mathrm{~b}$ shows the effect of packaging materials on protein content of GMEs with storage. The protein content generally decreased with storage time and the decrease observed followed a similar pattern which implies that packaging materials had no significant effect on the observed decrease in protein contents over the storage period. These results suggest that processing variables were responsible for the general decrease in protein content and that GME could be stored in any of these packaging materials without any significant changes in the protein content.

\section{Effects of processing variables on the fat content of GME during storage}

Figure 2 a shows changes in the fat content of GME stored in different packaging materials. The fat content of the GMEs on day 0 ranged between 2.4 and $3.4 \%$, and these are within the range for different vegetable milk extracts reported by Onweluzo and Nwakalor (2009). As storage time increased, the fat content of GME stored in plastic and glass bottles decreased. The fat content of milk obtained from whole and roasted groundnut decreased averagely to about $65 \%$ of the initial value at day 28. In contrast, the fat content of milk obtained from steeped groundnut only decreased by $\sim 18 \%$. This difference in fat content was significant $(p<0.05)$ and the relationship was maintained throughout the storage period and was observed in all the different packaging materials. The percentage change in loss of fat over the storage period was greatest, on the average, in milk from whole groundnut (40\%) and least, on the average in milk from steeped groundnut (18.5\%).

The low fat content of groundnut milk is an advantage for the keeping quality of the product as the probability of rancidity taking place would be greatly reduced (SunnyRoberts et al., 2004). A generally decreasing value was also observed by Onyeike and Onwuka (1999) when they evaluated the physicochemical and sensory characteristics of melon milk samples prepared from roasted, autoclaved, boiled and germinated melon seeds. Also, a similar trend was observed in soymilk prepared from dehulled and undehulled samples (Akanni et al., 2005). Adoga (2006) has attributed this loss to the action of lipases and other lipolytic enzymes some of which are 

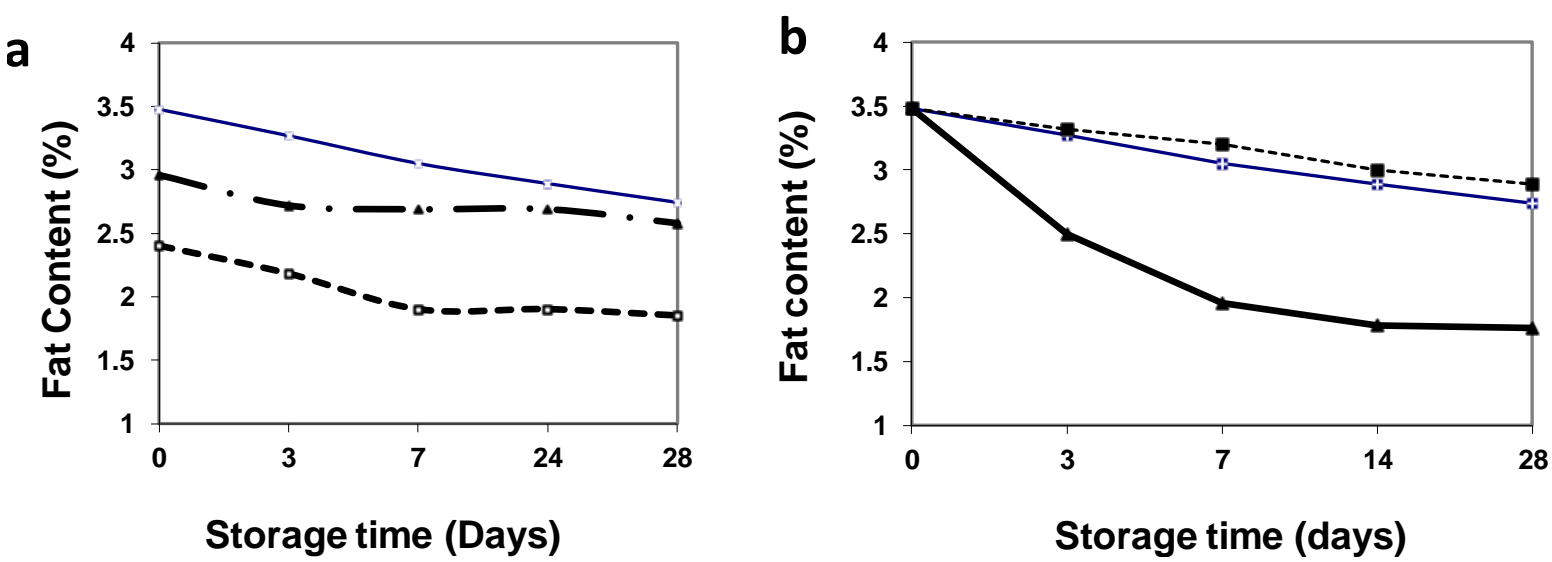

Figure 2. Effect of pretreatment and packaging material on the fat content of stored groundnut milk: A: $\Upsilon$, Roasted: $\Upsilon$, whole; $\Delta$, steeped. B: $\Upsilon$, Plastic; $\Upsilon$, glass; $\Delta$, sachet.
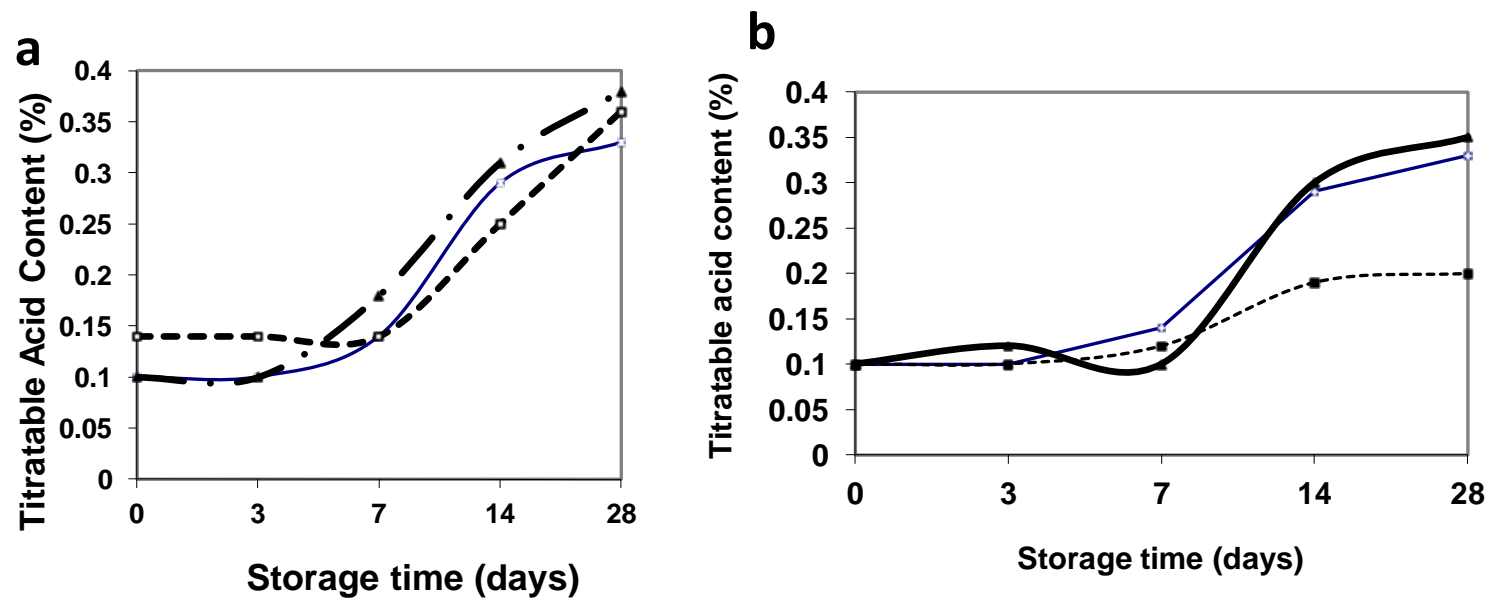

Figure 3. effect of pretreatment and packaging material on the titratable acidity of stored groundnut milk: A: $\Upsilon$, Roasted: $\Upsilon$, whole; $\Delta$, steeped. B: $\Upsilon$, Plastic; $\Upsilon$, glass; $\Delta$, sachet.

present in milk or secreted by organisms.

Figure $2 \mathrm{~b}$ shows that the fat content was stable in milk stored in plastic and glass bottles over the storage period (irrespective of the method of pretreatment) while there was a significant drop in the fat content of milk stored in sachet from about $2.2 \%$ on day 5 to about $1.3 \%$ by day 28. This result suggests that sachet (LPDE) may not be a good packaging material for roasted and whole milk.

\section{Effects of processing variables on the titratable acidity of GME}

The titratable acidity (TTA) value of GME remained relatively stable up to the $3^{\text {rd }}$ day in all packaging materials after which it began to increase especially in sachet and plastic bottles. This increase continued until the end of the storage period on day 28 when the level had increased more than $100 \%$ except in milk from whole groundnut stored in glass. The greatest increase in titratable acidity was observed between the $7^{\text {th }}$ and $14^{\text {th }}$ day (Figures $3 a$ and $b$ ). It is probable that the increase in the titratable acid may be as a result of anaerobic microbial activities resulting in the formation of lactic acid and other organic acids. The values observed in this study $(0.15$ to 0.35$)$ are less than reported $(0.24$ to 0.36$)$ by Onweluzo and Nwakalor (2009) for different vegetable milk extracts and Sunny-Roberts et al. (2004) for fermented groundnut milk. By the $28^{\text {th }}$ day the concentration of organic acid in plastic and sachet had risen averagely by $200 \%$ while it only rose averagely by $100 \%$ in glass within the same period. Other authors have reported an increase in TTA with storage and the extent of increase was influenced by the type of lactic acid bacteria present (Sanni et al., 1999, and Bucker et al., 2008). This result suggests that glass bottles are 
Table 4. Visual observation of refrigerated GME with time (stability test).

\begin{tabular}{lllll}
\hline \multirow{2}{*}{ Day } & \multicolumn{3}{c}{ GME from } & \multirow{2}{*}{ Visual observation } \\
\cline { 2 - 4 } & Roasted groundnut & Whole groundnut & Steeped groundnut & \\
\hline 3 & Wholesome & Wholesome & Wholesome & Milky \\
7 & Watery & Watery & Watery & Off-white \\
14 & Coagulated & Coagulated & Coagulated & Off-white \\
28 & Coagulated & Coagulated & Coagulated & Off-white \\
\hline
\end{tabular}

Wholesome, smooth continuous liquid; Watery, consistency thinner than normal some coagulated particles; Coagulated, small whitish particles floating in clear liquid; Off white colour, opalescent, beginning to turn from the white colour to light brownish.

more favourable for the storage of GME on account of slower acid formation. Unlike sachets and plastic bottles, glass containers are not permeable to gases which cause oxidative changes to lipids and other organic substances in food (Adoga, 2006). Fresh milk contains practically no lactic acid but the developed acidity is the result of bacterial activity producing lactic acid during milk processing. The developed acidity will be more pronounced if the milk is not cooled properly (FAO, 2008).

\section{Effects of processing on some parameters of GME}

The specific gravity of the various GMEs ranged between 1.031 and 1.037 with no discernible trend in the effect of temperature or storage material but marginal increase with longer storage period was observed. The New York Department of Agriculture fixed the range of acceptable specific gravity in unadulterated milk ranging between 1.030 to 1.034 (Pearson, 1981).

GME from roasted groundnut was the most viscous (7.66 cP) while milk from steeped groundnut was the least viscous $(7.33 \mathrm{cP})$. Viscosity increased marginally with storage time but effect of pretreatment was not significant on the viscosity values. The viscosity of GME stored in plastic containers ranged roasted (7.56 to 7.66 ), whole (7.45 to 7.52 ) and steeped (7.33 to 7.45$)$. In glass containers, the viscosity values for GMEs from roasted samples was (7.56 to 7.58 ), whole (7.45 to 7.50$)$ and steeped groundnut samples (7.33 to 7.36). GMEs packaged in sachet had viscosity values (7.56 to 7.62$)$ for roasted, whole (7.45 to 7.62 ) and steeped (7.33 to 7.56 ). The viscosity of milk generally increased with increasing period of storage but the rate of increase varied with the packaging material. There was minimal increase in samples stored in glass (max. $0.05 \mathrm{cP}$ ) while the samples stored in sachet had more pronounced increases in viscosity (max. $0.17 \mathrm{cP}$ ). Viscosity of milk and milk products is important in determining the rate of creaming of the milk and the rate of mass and heat transfer.

\section{Visual observation of stored groundnut milk with time (stability test)}

The results of the visual observation of the changes in the GME consistency and colour with storage are presented in Table 4 . The milk retained its creamy-white colour up till the $3^{\text {rd }}$ day and became opalescent white by the $7^{\text {th }}$ day. By the seventh day, milk from all three samples (roasted, steeped and whole) had changed in their appearance from the normal smooth continuous liquid to a watery consistency with fine coagulated particles. By the $14^{\text {th }}$ day curds (coagulated particles) had formed in all the milk samples. This is in keeping with the report of Annibaldi (1961) where milk with no preservatives had formed curds by the $9^{\text {th }}$ day. Brough et al. (1993) also reported different degrees of coagulation in some vegetable milk extracts. Prolongation of the stability of GME will require the addition of preservatives such as is commonly employed in commercial milk.

\section{Sensory attributes of groundnut milk}

Table 5 shows the results of the sensory evaluation of GMEs compared with commercial soya milk and commercial cow milk. Milk from roasted groundnut was judged the best in colour, appearance and flavour and these differences were statistically significant $(p<0.05)$. There were no significant differences $(p>0.05)$ between the samples with respect to taste and mouth feel. When compared to the commercial milk samples, the GMEs were understandably of lesser sensory appeal. The commercial samples had been fortified with flavours, preservatives and even vitamins and mineral supplements which enhanced its sensory and visual appeal. Within this limitation however, the GMEs compared favourably with the commercial samples especially in appearance, taste mouth feel and colour. In particular, milks from roasted and whole groundnut were considered better than commercial soymilk in mouth feel, while milk from roasted groundnut was better than commercial soymilk in colour (Table 5). This agrees with the sensory evaluation result 
Table 5. Mean scores of GMEs and commercial soy and cow milk.

\begin{tabular}{lccccc}
\hline \multirow{2}{*}{ Attribute } & \multicolumn{5}{c}{ Sample } \\
\cline { 2 - 6 } & $\begin{array}{c}\text { GME from roasted } \\
\text { groundnut }\end{array}$ & $\begin{array}{c}\text { GME from whole } \\
\text { groundnut }\end{array}$ & $\begin{array}{c}\text { GME from steeped } \\
\text { groundnut }\end{array}$ & $\begin{array}{c}\text { Commercial soy } \\
\text { milk }\end{array}$ & $\begin{array}{c}\text { Commercial peak } \\
\text { milk }\end{array}$ \\
\hline Appearance & $6.42^{\mathrm{a}}$ & $6.00^{\mathrm{ab}}$ & $4.12^{\mathrm{b}}$ & $6.92^{\mathrm{a}}$ & $7.75^{\mathrm{a}}$ \\
Flavour & $5.33^{\mathrm{ab}}$ & $4.75^{\mathrm{ab}}$ & $5.50^{\mathrm{ab}}$ & $6.33^{\mathrm{a}}$ & $8.33^{\mathrm{a}}$ \\
Taste & $6.17^{\mathrm{ab}}$ & $6.00^{\mathrm{ab}}$ & $5.42^{\mathrm{ab}}$ & $6.58^{\mathrm{a}}$ & $8.25^{\mathrm{a}}$ \\
Mouth feel & $6.08^{\mathrm{ab}}$ & $6.17^{\mathrm{ab}}$ & $6.00^{\mathrm{ab}}$ & $6.00^{\mathrm{ab}}$ & $8.17^{\mathrm{a}}$ \\
Colour & $7.17^{\mathrm{ab}}$ & $5.83^{\mathrm{a}}$ & $4.67^{\mathrm{ab}}$ & $6.75^{\mathrm{a}}$ & $7.58^{\mathrm{a}}$ \\
Overall acceptability & $6.00^{\mathrm{ab}}$ & $5.75^{\mathrm{ab}}$ & $5.25^{\mathrm{b}}$ & $7.08^{\mathrm{a}}$ & $8.42^{\mathrm{a}}$ \\
\hline
\end{tabular}

*Means within a row followed by different letters are significantly different $(p<0.05)$

of GME from bambara groundnut (Brough et al., 1993). Roasting imparts a characteristic flavour to groundnut which is due to amino acid and carbohydrate reacting to produce hydrofuran derivatives (Ahmed and Young, 1982). The brownish discolouration and dehydration from roasted groundnuts also imparted a thick brownish consistency to the resulting milk hence improving its appearance. Overall, milk from roasted groundnut was more acceptable than milk from whole or steeped groundnut.

\section{Conclusions}

Processing variables such as steeping and roasting had significant effects on the physico-chemical as well as storage characteristics of groundnut milk extracts. Glass bottle was the most suitable packaging material for storage of GME followed by plastic bottles and sachet was found to be the least suitable for storing GME due to its permeable nature. GME from roasted groundnut had the best sensory appeal. Of the three pretreatments studied, milk from roasted groundnut had the best sensory appeal, comparable fat content, stable specific gravity, minimal protein decrease and was unchanged by the third day of storing. The extraction procedure requires no specialized equipment and is suitable for village-level processing. Further studies need to be conducted to improve the shelf life using preservatives, stabilizer and or emulsifier and also addition of flavours.

\section{REFERENCES}

Adoga Gl (2006). Role of lipolytic enzymes in the deterioration of groundnut (Arachis hypogaea) cakes: A comparison with fresh milk. Soc. Chem. Ind. 41:61-68

Ahmed EH, Young CT (1982). Composition, nutrition and flavour of peanut. J. Am. Peanut Res. Edu. Soc. 11:655-687.

Akanni MS, Adekunle AS, Oluyemi EA (2005). Physico-chemical properties of some non-conventional oil seeds. J. Food Tech. 3:177 $-181$.

Akinyele IO (1983). Combination of cereals and legumes and meat in extrusion processing. In Role of cereals and legumes in nutrition (Dupont and Osman, eds) lowa State University Press. pp. 219 236.
Alkanhal HA (2000). Suitability of methods used for the measurement of proteolysis in UHT milk. Aust. J. Dairy Tech. 55:148-152.

Annibaldi S (1961). Evaluation and importance of the contractility of rennet curd. Scienza Tecnica Lattiero-Casearia. 11:17-19.

AOAC (1990). Official Methods of Analysis. Association of Official Analytical Chemists, Washington, DC.

Asiamah K (2005). Process optimization of cowpea-peanut milk. M.Phil. Thesis, Department of Nutrition and Food Science, University of Ghana.

Beuchat LR, Nail BJ (1978). Fermentation of peanut milk with Lactobacillus bulgaricus and L. acidophilus. J. Food Sci. 43: 1109-1112.

Brough SH, Azam-Ali SN, Taylor AJ (1993). The potential of bambara groundnut (Vigna subterranea) in vegetable milk production and basic protein functionality systems. Food Chem. 47(3):277-283.

Bucker JR, Mitchell JH, Johnson MG (2008). Lactic acid fermentation of peanut milk. J. Food Sci. 44(5):1534-1538.

Diarra K, Nong ZG, Jie C (2005). Peanut milk and peanut milk based products production: A review. CRC Crit. Rev. Food Sci.Nutr. 45:405-423

Evangelisti F, Caalcagno C, Nardi S, Zunin P (1999). Deterioration of protein fraction by Maillard reaction in dietetic milks. J. Dairy Res. 66:237-243.

Ferrer E, Alegria A, Farre R, Abellan P, Romero F (2000). Effects of thermal processing and storage on available lysine and furfural compounds content of infant formulas. J. Agric. Food Chem. 48: $1817-1822$

Gbadamosi SO, Ogunsua AO (2006). Substitution of cowpea with soyflour/cassava starch in moin-moin preparation. J. Food Tech. 4(4): 303-307.

Ihekoronye Al, Ngoddy PO (1985). Integrated food science and technology for the tropics. (A.I. Ihekoronye and P.O. Ngoddy, eds) Macmillan Publishers Company Limited. London, U.K. pp. 40-65.

Miller R (2000). Food nutrient analysis of peanuts: the food chain. Food Agric. 4:78-83.

Ojofeitimi EO, Abiose SH, ljadunola KT, Pedro T, Jinadu MK (2001). Modification and improvement of nutritive quality of corn pap "ogr" with cowpea and groundnut milk, J. Nutr. Health 15:43-53

Olaofe O, Sanni CO (1988). Mineral contents of agricultural products. Food Chem. 30:73-77.

Onweluzo JC, Nwakalor C (2009). Development and Evaluation of Vegetable Milk from Treculia africana (Decne) Seeds. Pakistan J. Nutr. 8:233-238.

Onweluzo JC, Owo OS (2005). . Stabilization potential of water soluble polysaccharide from two indigenous legumes (Detarium microcarpum and Mucuna flagellipes) in vegetable milk: Effects on selected quality characteristics. J. Home Econ. Res. 6:39-44.

Onyeike EN, Onwuka O (1999). Chemical composition of some fermented vegetable seeds used as soup condiments in Eastern Nigeria. Glob. J. Pure App. Sci. 5:337 - 342 .

Oyenuga VA (1968). Nigeria's Foods and Feeding Stuff. Ibadan University Press, Ibadan, Nigeria. pp. 68-75.

Pearson D (1981). Chemical Analysis of Foods, Churchill Livingstone, London. pp. 101-132. 
Potter NN, Hotchkiss JH (1996). Food Science, CBS Publishers and Distributors Pvt. Ltd. New Delhi. pp. 279-314

Priepke PE, Well LS, Nelson AI, Steinberg MO (1980). Suspension stability of Illinois beverages. J. Food Sci. 52:242 - 245

Sanni Al, Onilude AA, Adeleke EO (1999). Preparation and characteristics of Lactic acid fermented cowpea milk. Lebensm Unters Forsch, A 208:225-229

Sunny - Roberts EO, Otunola ET, Iwakun BT (2004). An evaluation of some quality parameters of a laboratory prepared fermented groundnut milk. Euro. Food Res. Technol. 218:452 - 455.
Wang Y, Yu R, Yang C, Chou C (2003). Sugar and acid contents in soymilk fermented with lactic acid bacteria alone or simultaneously with bifidobacteria. Food Microbiol. 20:333-338

Wang Y, Yu R, Chou C (2002). Growth and survival of bifidobacteria and lactic acid bacteria during the fermentation and storage of cultured soymilk drinks. Food Microbiol. 19:501-508

Weiss TJ (1983). Physical and Chemical Properties of Fats and Oils. In: Food Oils and their uses. AVI Publishing Company Incorporated. Westport, USA. 2nd Ed. pp. 25 - 31, 44 - 84. 